\title{
Strategy of development and export potential of the grain complex of Russia. Regional aspect
}

\author{
B. A. Voronin ${ }^{1}$, M. Yu. Karpukhin ${ }^{1}$, I. P. Chupina ${ }^{1 \bowtie}$, Ya. V. Voronina ${ }^{1}$ \\ ${ }^{1}$ Ural State Agrarian University, Ekaterinburg, Russia \\ E-mail: irinacupina716@gmail.com
}

Abstract. Grain production and legal regulation of this industry are of paramount importance for the food security of the country. Therefore, the purpose of this study is to analyze the adopted laws and regulations governing relations in the field of grain and its processed products, as well as the state of grain growing in Sverdlovsk region. The article uses the methods of analysis and synthesis, the method of generalization, the method of environmental forecasting, as well as the method of strategic planning. The results of this article are based on the fact that the Law of the Russian Federation No. 4973-1 "On grain", adopted on 14 May 1993 (currently not in full force), established in the first article that grain is a national treasure of the Russian Federation, one of the main factors of economic stability. By decree of Government of Russian Federation No. 491 of 4 August 2005, state control over the quality and safety of grain, mixed feed and components for their production, as well as by-products of grain processing, is assigned to Federal Service for Veterinary and Phytosanitary Supervision. The scientific novelty lies in the fact that the law "On grain" has not become the main integrated legal act in the complex regulating relations in the field of grain growing. Therefore, at present, the most important legal act is the long-term strategy for the development of the grain complex of Russian Federation until 2035, which, according to the authors, should consider the organizational and economic mechanisms for the production of the grain complex in close interconnection, where high-quality grain should be provided with appropriate technologies at all stages of its production, as well as during transportation, storage and processing. Keywords: grain, grain processing product, legal regulation, state control and supervision, state grain inspection, technological regulations and long-term strategy.

For citation: Voronin B. A., Karpukhin M. Yu., Chupina I. P., Voronina Ya. V. Strategy of development and export potential of the grain complex of Russia. Regional aspect // Agrarian Bulletin of the Urals. 2020. No. 12 (203). Pp. 78-82. DOI: ...

Paper submitted: 27.10.2020.

\section{Introduction}

Grain growing is one of the most important subsectors of agriculture, providing the country's population with bread, bakery products, cereals, flour and other grain products. Grain is of great importance in the production of compound feed for agricultural animal husbandry.

As a result of the land and agrarian reform since 1990, the grain problem in the Russian Federation has sharply exacerbated, which led to a shortage of bread, cereals, flour and other products related to grain.

\section{Methods}

The theoretical and methodological basis was formed by a systematic approach to the study of the studied problem of grain growing in Russia and abroad. This work uses the provisions contained in Russian legislation, decrees of the President of Russia and other regulatory government acts.

In the process of studying and processing the used information sources in the analysis and synthesis, a combination of the generalization method, the environmental forecasting method, and the strategic planning method was used.

\section{Results}

Grain growing is one of the most important subsectors of agriculture, providing the population of the country with bread, bakery products, cereals, flour and other products of grain processing. Grain is of great importance in the production of compound feed for agricultural animal husbandry.

As a result of the land and agrarian reform since 1990, the grain problem in the Russian Federation has sharply aggravated, which led to a shortage of bread, cereals, flour and other products related to grain.

Reforms under open administrative pressure of stably operating state and collective farms and their transformation into new organizational and legal forms of management in the agricultural sector of the economy led to a crisis in agricultural production and a noticeable decrease in the number of agricultural organizations. Taken together, all this affected the fact that Russia began to purchase grain and products of its processing by import, this also affected the number of agricultural organizations and personal subsidiary farms of citizens. In confirmation of the latter, data are provided for the Sverdlovsk region

Understanding the current situation with grain and its processed products, the state adopted a special law "On Grain" and several bylaws aimed at regulating relations in the field of grain growing. 
Main indicators of agriculture in the Sverdlovsk region

\begin{tabular}{|l|c|c|}
\hline \multicolumn{1}{|c|}{ Cattle (thousand heads) } & $\mathbf{1 9 9 0}$ & $\mathbf{2 0 2 0}$ \\
\hline Cows, thousand heads & 344.0 & 116.8 \\
\hline Pigs, thousand heads & 606.3 & 341.1 \\
\hline Sheep and goats, thousand heads & 96.0 & 57.2 \\
\hline
\end{tabular}

${ }^{*}$ Data of the territorial department of state statistics for the Sverdlovsk region.

Table 2

Main indicators of agriculture in the Sverdlovsk region

\begin{tabular}{|l|c|c|}
\hline \multicolumn{1}{|c|}{ Gross harvest of grain crops } & $\mathbf{1 9 9 0}$ & $\mathbf{2 0 1 9}$ \\
\hline Gross harvest of grain and leguminous crops, thousand tons & 1088.3 & 701.8 \\
\hline Grain yield, c/ha & 15.3 & 22.4 \\
\hline
\end{tabular}

${ }^{*}$ Data of the territorial department of state statistics for the Sverdlovsk region.

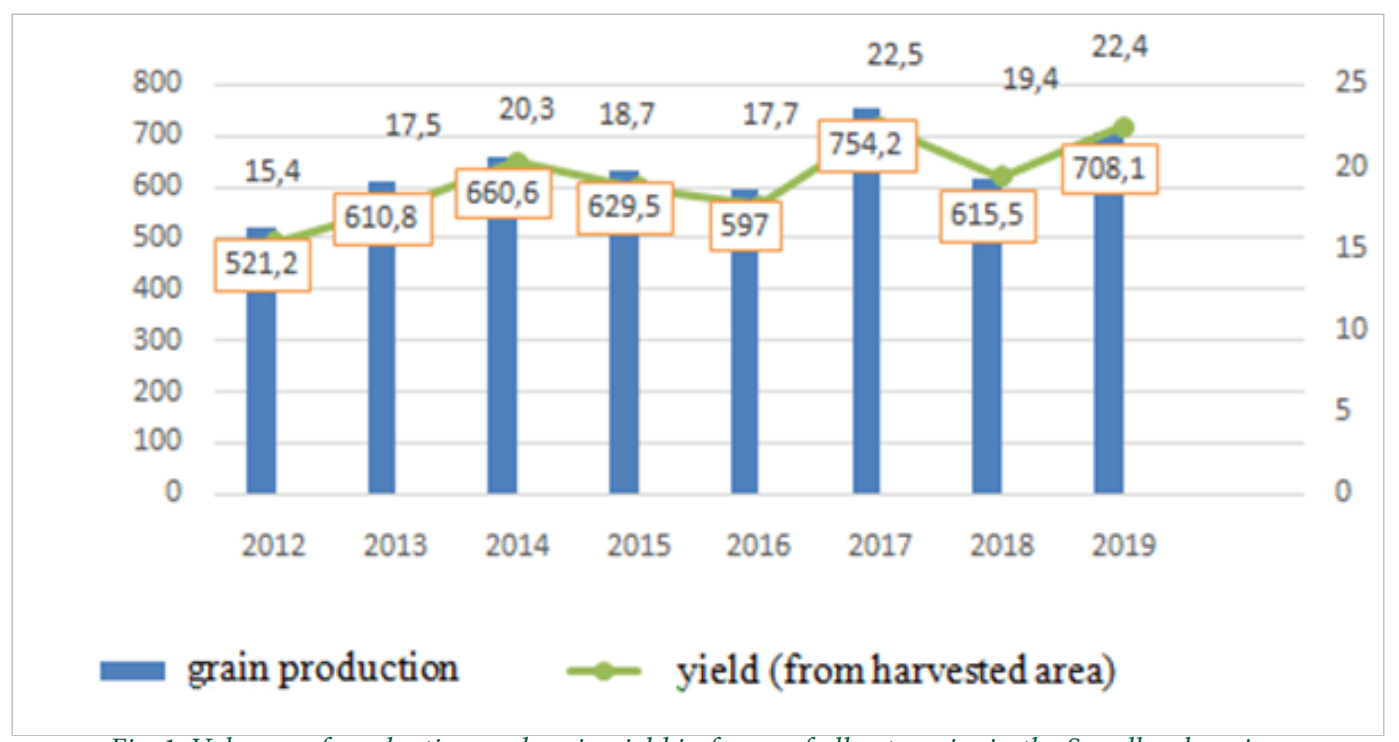

Fig. 1. Volumes of production and grain yield in farms of all categories in the Sverdlovsk region

(data from the bulletin of the Ministry of Agro industrial Complex and Consumer Market of the Sverdlovsk Region, 2019)

In addition to purely production tasks for the maintenance, and even more so for an increase in the production of grain crops, there were problems with grain storage facilities, elevators and other infrastructure facilities related to the storage and processing of grain products, since many facilities were destroyed and plundered during uncontrolled privatization. Until 1990, grain warehouses and other infrastructural facilities of the farm functioned in each state or collective farms; there were elevators, mills for grinding grain for fodder for livestock and poultry. All this was sold overnight, and a problem arose where to store the received grain, its benefit became less, since by half, and in some places at all, there was no public livestock and poultry farming.

In the same Sverdlovsk region, by 1990, 37 poultry farms and poultry farms functioned, in which there were grain infrastructure facilities and, naturally, grain was grown and (or) purchased for feed needs. As you can see, the need for grain for the production of fodder for livestock and poultry farming on the farms of the Sverdlovsk region has significantly decreased and affected the volume of grain production.

Comparative analysis with 1990 indicates a decrease in the production of grain and leguminous crops. Let us give the volume of production and grain yield in farms of all categories, where the small rates of development of grain growing in the Sverdlovsk region in recent years are confirmed [2].
In terms of climatic conditions, the territory of the Sverdlovsk Region is not successful in terms of growing grain crops. Podzolic soils prevail here. Humus contains no more than $5.13 \%$. The share of arable land in the region is approximately $15 \%$ of all areas. It ranks $36^{\text {th }}$ among other regions of the country in terms of production of winter and spring wheat. The production of oats, the region occupies $15^{\text {th }}$ among other regions.

For the production of rye, the Sverdlovsk region is in $24^{\text {th }}$ place among other regions. Triticale is also produced in the Sverdlovsk Region. Triticale is also produced in the Sverdlovsk Region. The collection volumes of winter and spring triticale averaged 2.8 thousand tons. This is about $0.5 \%$ of the total harvest of this crop in Russia as a whole. The Sverdlovsk region takes $38^{\text {th }}$ place in the disposal of this culture.

The grain industry can only develop with the support of the state, which influences the market through government purchases. Through state structures, the formation of state reserves and regional funds in the field of grain growing takes place. The stability of the entire agro-industrial complex primarily depends on the grain market.

If earlier, as already mentioned in this article, Russia bought grain from other countries, then during the period of economic sanctions the consequences would have been the most negative. Moreover, the Sverdlovsk region cannot be called developed for the production of grain crops [7]. 
For the production of high-quality grain, large financial investments is required, therefore the role of the state is very important, since this process cannot be launched without a stable demand for grain products.

If you look at the statistics of the Ural Federal District, then only up to 5 million tons of grain is produced here, while in the Southern Federal District more than 36 million tons, in the Volga region - up to 30 million tons, in the North Caucasian District and in Siberia up to 18 million tons. Of the 4 regions of the Ural Federal District, Chelyabinsk and Kurgan regions are in first place - they produce 2 million tons of grain each, the Tyumen region produces 1.5 million tons, but the Sverdlovsk region only 0.6 million tons. Therefore, the region is dependent on other regions for grain, although livestock and poultry farming is developed here. We can say that the threshold of food security in the Sverdlovsk region is critical for grain.

There are no significant prospects for the grain market yet. Therefore, crops and leguminous crops in the region are declining, and there is a reduction in agricultural machinery in agricultural enterprises [10].

If earlier there were certain standards, where each farm was obliged to hand over a certain amount of grain to the state, now this is not the case, and the exchange form appeared to replace the state regulation of grain.

Grain as a commodity for exchange trading is only being mastered, but this has already made a certain contribution. Since 2017, the yield in some farms in the Sverdlovsk region has reached from 30 to $40 \mathrm{c} / \mathrm{ha}$. This is the Irbitskiy district, Kamenskiy, when the average regional volume was $18 \mathrm{c} / \mathrm{ha}$. The reduction of agricultural machinery is also of great importance. In recent years, the region has seen a decrease in tractors by more than 1,000 units, grain harvesters by 200 units. Of course, new modern technology appears to replace the old one. But one new harvester cannot replace ten old ones.

The application of mineral fertilizers should be especially noted. If in the USA and Canada $240 \mathrm{~kg}$ of fertilizers are applied per hectare, and in China even twice as much as in the USA and Canada, then in Russia only $28 \mathrm{~kg}$.

There are also problems with grain safety. More than $70 \%$ of the grain is stored in conditions that do not meet the standards, i.e. stored outdoor in hangars of farms. Not all elevators meet modern requirements. Concrete elevators can provide the best preservation of grain, based on research by the Ministry of Agriculture of the Russian Federation. Only 1/4 part of all grain grown in the region is stored on elevators in the region. The rest of the grain is stored on farms.

And when harvesting grain in the fields, it is lost up to 4-6\%. The Sverdlovsk Region produces on average up to 70 thousand tons of food grain, and consumes up to 400 thousand tons.

So far, only individual farms of the region can be cited as examples. The leader here is the Ural collective farm. The highest grain yield is in the Kilachevsky agricultural enterprise $-54 \mathrm{c} /$ ha. Here they grow wheat of the Zlata variety, which has proven itself well. Also, the new wheat variety "Likamero" gave $82 \mathrm{c} /$ ha.

Despite the use of imported seed, as well as seeds of the elite class of domestic breeding, in general, the yield of grain and leguminous crops is still far from foreign agriculture. Ap- parently, the reason here lies in the organizational and economic mechanisms. High-quality grain should be provided with appropriate technologies at all stages of its production, as well as during transportation, storage and processing. All these conditions are defined in the law "On grain" and by-laws governing relations in this area.

The Law "On Grain", as mentioned above, did not become the main integrated legal act in the complex regulating relations in the field of grain growing, since its individual norms were not developed in a market economy, and other areas required the adoption of additional legislative and other legal acts. For example, a special law "On state supervision and control over the quality and safety of grain and its processed products" or the decree of the President of the Russian Federation № 2280 of December 24, 1993 was adopted. "On the liberalization of the grain market in Russia" and other bylaws. Although, according to the rules of legal technique, the listed acts and others could be in the structure of the Law "On Grain" or it would be possible to develop and adopt a separate set of legal acts regulated in the complex of relations in the field of grain and its processed products. As a result, many additional normative legal acts have been adopted today, which are separately aimed at regulating relations in the field of grain growing. Currently, the most important legal act is the Longterm strategy for the development of the grain complex of the Russian Federation until 2035 [1]. The strategy is the basis for the development of state programs of the Russian Federation and other strategic planning documents stipulated by the legislation of the Russian Federation, containing measures aimed at developing the grain complex. The strategy is a industry document of the strategic planning of the Russian Federation in the grain sector, defining the priorities, goals and objectives of public administration and ensuring the food security of the Russian Federation, ways to effectively achieve and solve them comprehensively.

The Strategy defines that the grain complex of the Russian Federation is a combination of sub-sectors of agriculture, food and processing industry, transport, wholesale and retail trade, providing production, transportation, storage, processing and sale of grain and grain legumes and products of their processing in the domestic and foreign markets [17].

It is very good that government bodies are concerned about the development of the largest and most socially significant sub-sector of agriculture in the future. The list of directions for the development of the country's grain complex, defined in the Long-term strategy, involves the organization of serious and responsible work, scientists, specialists, agricultural entrepreneurs and partners in the agro-industrial complex. Great importance is attached to the export of grain, primarily to the states that are members of the Customs Union. The legal document here is the customs regulations of the Customs Union TR CU 015/2011 "On the safety of grain", approved by the decision of the Customs Union Commission of December 9, 2011 № 874.

This technical regulation applies to grain released into circulation in the common customs territory of the Customs Union, used for food and feed purposes.

This technological regulation does not apply to grain intended for seed purposes, grain processing products. 
The technical regulation establishes the requirements for grain and related requirements for the processes of production, storage, transportation, sale and disposal of grain, binding for application and execution in the unified customs territory of the Customs Union, in order to protect human life and health, property, environment, life and animal and plant health, as well as prevention of actions that mislead grain consumers [16].

The Long-term strategy for the development of the grain complex of the Russian Federation until 2035 provides a detailed analysis of the internal and external environment of the grain complex of the Russian Federation, which analyzes the factors of the internal and external environment related to the strengths of the grain complex of the Russian Federation, as well as the factors of the internal and external environment related to weaknesses of the grain complex of the Russian Federation. According to the factors considered, the strong and weak environments are practically equal, although in terms of the content and direction of impact on the development of the grain complex, many of the indicated factors will require significant financial resources and time to implement.

\section{Discussion and Conclusion}

An analysis of the laws and other legal acts given in the article that regulate grain growing in modern Russia shows that, in the aggregate, the problems of grain and its processed products, when in demand in the domestic and foreign markets, have not yet been fully resolved. The yield of grain crops is still not high in comparison with European countries and, especially, the United States, Canada and other world graingrowing countries: the reasons are that the rate of increase in yield on average in Russia does not grow in part. For example, in the Sverdlovsk region, since 1990, the yield has varied within $12-18 \mathrm{c} / \mathrm{ha}$. Although there are individual farms where the yield reaches $40-50 \mathrm{c} / \mathrm{ha}$. This is achieved by the quality of seeds of grain and leguminous crops, timely change of variety and variety renewal, the use of effective technologies and good organization of agriculture and grain growing. As Academician A. A. Zhuchenko notes [3]. "The priority direction of grain farming in our country opens up not only great opportunities for the successful functioning of all branches of the agro-industrial complex and, first of all, animal husbandry, but also for achieving the most efficient use of the agro-climatic potential of most of the country's agricultural territories".

July 21, 2020 President of the Russian Federation V. V. Putin signed the Decree "On the national development goals of the Russian Federation for the period up to 2030". Among the national goals is ensuring food security and stable export of grain and its processed products, which means that the Longterm strategy for the development of the grain complex of the Russian Federation until 2035 should organically flow into the general list of national goals and must be fulfilled. We only need the effective organizational, legal and economic mechanisms for its implementation.

\section{References}

1. Rasporyazhenie Pravitel'stva RF ot 10 avgusta 2019 g. No. 1796-r [Long-term strategy for the development of the grain complex of Russian Federation until 2035. Approved by the decree of Government of Russian Federation No. 1796-r dated 10 August 2019] [e-resource]. URL: http://www.garant.ru/products/ipo/prime/doc/72522534/?_utl_t=vk (appeal date: 09.10.2020). (In Russian.)

2. Gumerov R. R. Rossiyskiy zernovoy eksport: ne povtoryat' oshibok proshlogo [Russian grain exports: not to repeat the mistakes of the past] // The all-Russian ECO Journal. 2017. No. 1. Pp. 5-19. (In Russian.)

3. Garmashov V. M., Kornilov I. M., Nuzhnaya N. A., Govorov V. N., Kryachkova M. P. Methods for improving the quality of winter wheat grain // AgroForum. 2019. No. 1. Pp. 42-44.

4. Grebennikov A. M., Frid A. S., Saprykin S. V., Cheverdin Yu. I. Vliyanie primeneniya razlichnykh sposobov osnovnoy obrabotki na zapasy produktivnoy vlagi $\mathrm{v}$ agrochernozemakh [The influence of the use of various methods of basic processing on the reserves of productive moisture in agrochernozems] // Agrochemistry. 2019. No. 8. Pp. 40-47. (In Russian.)

5. Deinekin S. A. Analiz kachestva zerna liniy ozimoy rzhi, vydelivshikhsya po zakrepitel'noy sposobnosti [Analysis of the grain quality of winter rye lines, distinguished by the fixing ability] // Central Scientific Bulletin. 2019. No. 13. Pp. 4-6. (In Russian.)

6. Derbeneva E. V. Polushkina T. M. Sravnitel'nyy analiz zarubezhnogo i rossiyskogo opyta organizatsii ispol'zovaniya sel'skokhozyaystvennykh zemel' [Comparative analysis of foreign and Russian experience in organizing the use of agricultural land] // Scientific Review. Economic sciences. 2016. No. 6. Pp. 51-54. (In Russian.)

7. Dorokhov B. A., Vasilyeva N. M. Sovremennye pogodnye usloviya i ikh vozdeystvie na khozyaystvennye pokazateli ozimoy pshenitsy [Modern weather conditions and their impact on economic indicators of winter wheat] // International Journal of Humanities and Natural Sciences. 2019. No. 11-2 (38). Pp. 106-111. (In Russian.)

8. Evdokimov M. G., Yusov V. S., Pakhotina I. V. Zavisimost' urozhaynosti i kachestva zerna tverdoy yarovoy pshenitsy ot meteorologicheskikh faktorov v yuzhnoy lesostepi Zapadnoy Sibiri [Dependence of yield and grain quality of durum spring wheat on meteorological factors in the southern forest-steppe of western Siberia] // Grain economy of Russia. 2020. No. 5. Pp. 26-31. (In Russian.)

9. Kostrova Yu. B., Shibarshina O. Yu. Analiz i perspektivy razvitiya zernovogo rynka v RF [Analysis and prospects for the development of the grain market in the Russian Federation] // Azimuth of scientific research: economics and management. 2018. Vol. 7. No. 2. P. 177. (In Russian.)

10. Krivobochek V. G., Statsenko A. P., Goreshnik I. D., Kapustin D. A., Yurova Yu. A. Fermentnye sistemy v otsenke zasukhoustoychivosti yarovoy pshenitsy [Enzyme systems in assessing drought resistance of spring wheat] // Agrarian scientific journal. 2015. No. 7. Pp. 23-26. (In Russian.) 
11. Malokostova E. I., Pivovarova I. Yu., Popova A. V. Otsenka selektsionnykh liniy i sortov yarovoy pshenitsy po selektsionnym indeksam [Assessment of breeding lines and varieties of spring wheat by breeding indices] // Bulletin of Michurinsky GAU. 2019. No. 1. Pp. 24-27. (In Russian.)

12. Piskareva L. A., Bocharnikova E. G. Izmenenie struktury i urozhaynosti ozimoy pshenitsy pod vliyaniem agrokhimikatov na razlichnykh urovnyakh udobrennosti [Changes in the structure and yield of winter wheat under the influence of agrochemicals at different levels of fertilization] // Central Scientific Bulletin. 2019. No. 9 (74). Pp. 7-8. (In Russian.)

13. Popov A. S. Sroki poseva tverdoy ozimoy pshenitsy [Sowing dates for durum winter wheat] // Grain economy of Russia. 2019. No. 6. Pp. 28-32. (In Russian.)

14. Turusov V. I., Garmashov V. M. Prognozy na urozhay 2019 goda [Predictions for the 2019 harvest] // Voronezh Agrovestnik. 2019. No. 7 (196). Pp. 25-27. (In Russian.)

15. Filippov E. T., Dontsova A. A., Bragin R. N. Otsenka pokazateley adaptivnosti sortov ozimogo yachmenya v usloviyakh yuga Rossii [Assessment of indicators of adaptability of varieties of winter barley in the south of Russia] // Grain economy of Russia. 2019. No. 4. Pp. 14-18. (In Russian.)

16. Voronin B. A., Chupina I. P., Kot E. M., Mokronosov A. G. Consequences of Economic Sanctions For Food Security of Russia // International journal of Advanced Biotechnology and Research (IJBR). Vol. 9. Iss. 1. Pp. 1023-1028.

17. Chupina I. P. Problemy ekologicheskoy bezopasnosti v Rossii [The problems of ecological safety in Russia] // Global challenges of contemporary issues: collection of scientific articles. Paris, France, 2018. Pp. 34-37. (In Russian.)

\section{Authors'information:}

Boris A. Voronin ${ }^{1}$, doctor of law, professor, director of the Research institute of agrarian and environmental problems and agricultural management, ORCID 0000-0002-0912-7839, AuthorID 574258; + 7 (343) 221-40-47

Mikhail Yu. Karpukhin ${ }^{1}$, candidate of agricultural sciences, associate professor, vice-rector for research and innovation, ORCID 0000-0002-8009-9121, AuthorID 339196

Irina P. Chupina ${ }^{1}$, doctor of economic sciences, professor of the department of management and law, ORCID 0000-0003-2875-3306, AuthorID 648263; + 7 (343) 221-41-12

Yana V. Voronina ${ }^{1}$, candidate of economic sciences, associate professor of the department of management and law, ORCID 0000-0002-4271-6264, AuthorID 874832; + 7 (343) 221-41-12

${ }^{1}$ Ural State Agrarian University, Ekaterinburg, Russia 